\title{
Prevalence of Frozen Shoulder among Diabetes Mellitus Patients: a cross cut survey
}

\author{
Easmin Ara Doly* \\ Chief Physiotherapist, Firoza Bari Disabled Children Hospital, Bangladesh
}

Submission: November 17, 2017; Published: November 28, 2017

*Corresponding author: Easmin Ara Doly, Chief Physiotherapist, Firoza Bari Disabled Children Hospital, Bangladesh, Email: cnbuhs2013@gmail.com

\begin{abstract}
Sufferings of frozen shoulder patients know no bounds. Adding diabetes with frozen shoulder make it more complicated. This short term cross cut survey was conducted to assess prevalence of frozen shoulder among diabetes mellitus patients. Diabetes was confirmed by checking diabetes book or medical records. Frozen shoulder was detected first in the outdoor and later during interview also. Average age of the patient's was $53.16 \pm 11.39$ years. Half of the patients were graduate. Service holder, businessman, housewife, retired, farmer and day labor were $28 \%$, $24 \%, 20 \%, 16 \%, 8 \%$ and $4 \%$ respectively. Average monthly family income of the patients was $29908.00 \pm 13640.89$ BDT. More than half of the patients $(53.6 \%)$ earned $\leq 30000$ BDT. Prevalence of frozen shoulder among diabetic patients was $14.40 \%$.No statistical association was found between frozen shoulder and gender $(\mathrm{p}=0.488>0.05)$.So it is concluding that prevalence of frozen shoulder among diabetes patients is still high enough. Why frozen shoulder is increasing among diabetic patients -can be studied extensively in future.
\end{abstract}

Keywords: Frozen Shoulder; Diabetes Mellitus

\section{Introduction}

Frozen shoulder is a painful condition where pain increases during certain shoulder movement [1]. Affected in early age is rare but initiates after sixth decade of life [2]. Women suffered more than male [3]. It is evidence based that inactive shoulder is slightly more likely to be affected than active shoulder $[4,5]$. In our day to day practice observing that number of frozen shoulder patients is high among patients with diabetes mellitus. When I apply physiotherapy to them find difficulty to manage and progress is slow. Literature suggests that secondary frozen shoulder may be associated with diabetes mellitus [6]. The prevalence of FS in diabetes patients is reported to be $10 \%-36 \%$ $[7,8]$. But what is the scenario in our country Bangladesh need to be explored timely because of high rising tendency of diabetes mellitus patients. This cross cut study is an attempt to fill up this knowledge gap.

\section{Materials and Method}

This was a cross cut survey like study conducted at SherE-Bangla Nagar Orthopedic hospital among 125 pre-diagnosed diabetic patients attending outpatient department for treatment. After diagnosis data were collected when they were referred to physiotherapy department for physiotherapy. Diabetes was confirmed by checking diabetes book or medical records. Sample was conveniently selected at definite time period. Verbal consent was taken before initiation of interview. Assurance was given about confidentiality of information and freedom to withdraw any stage of interview. Rechecking of shoulder movement and radiological evidence was done to over confirm about diagnosis of frozen shoulder.

\section{Results}

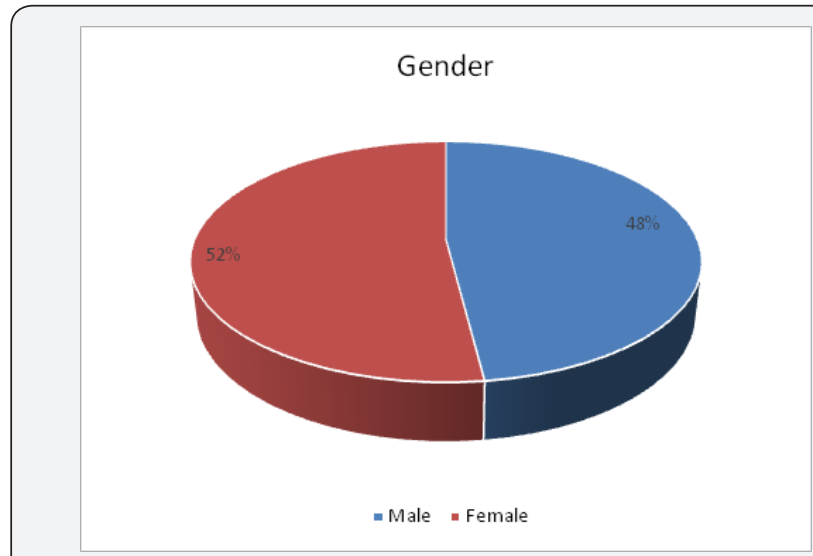

Figure 1: Gender distribution of the patients $(n=125)$. Male and female distribution was $48 \%$ and $52 \%$.

Average age of the patient's was $53.16 \pm 11.39$ years. Nearly half of the patients belonged to 35-50 years age group followed by $36 \%$ from $51-65$ years of age and $16 \%$ from $>65$ years of age 


\section{Orthopedics and Rheumatology Open Access Journal}

(Tables 1-3) (Figures 1-3). Results were published as number (\%), $\chi 2$ test was performed and $p<0.05$ was level of significance.

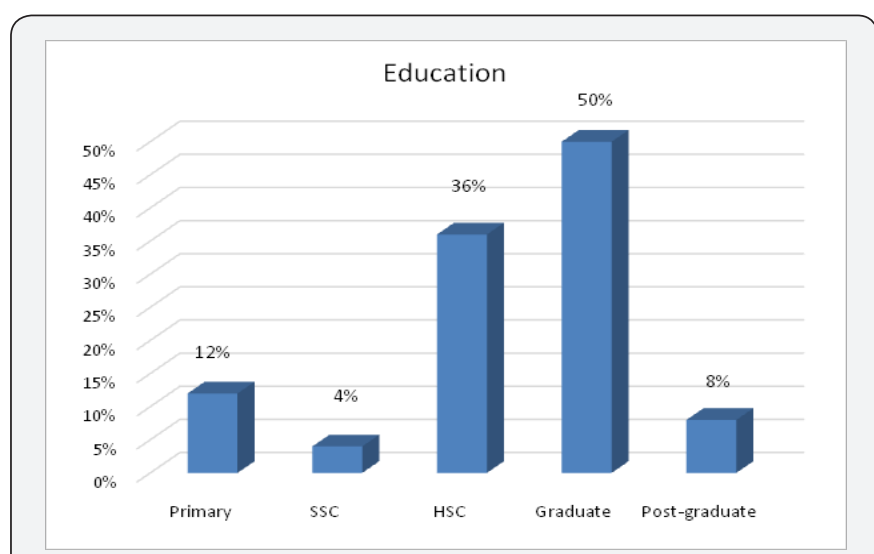

Figure 2: Educational level of the patients $(n=125)$.

Half of the patients were graduate followed by HSC $36 \%$, primary $12 \%$ and post-graduate $8 \%$.
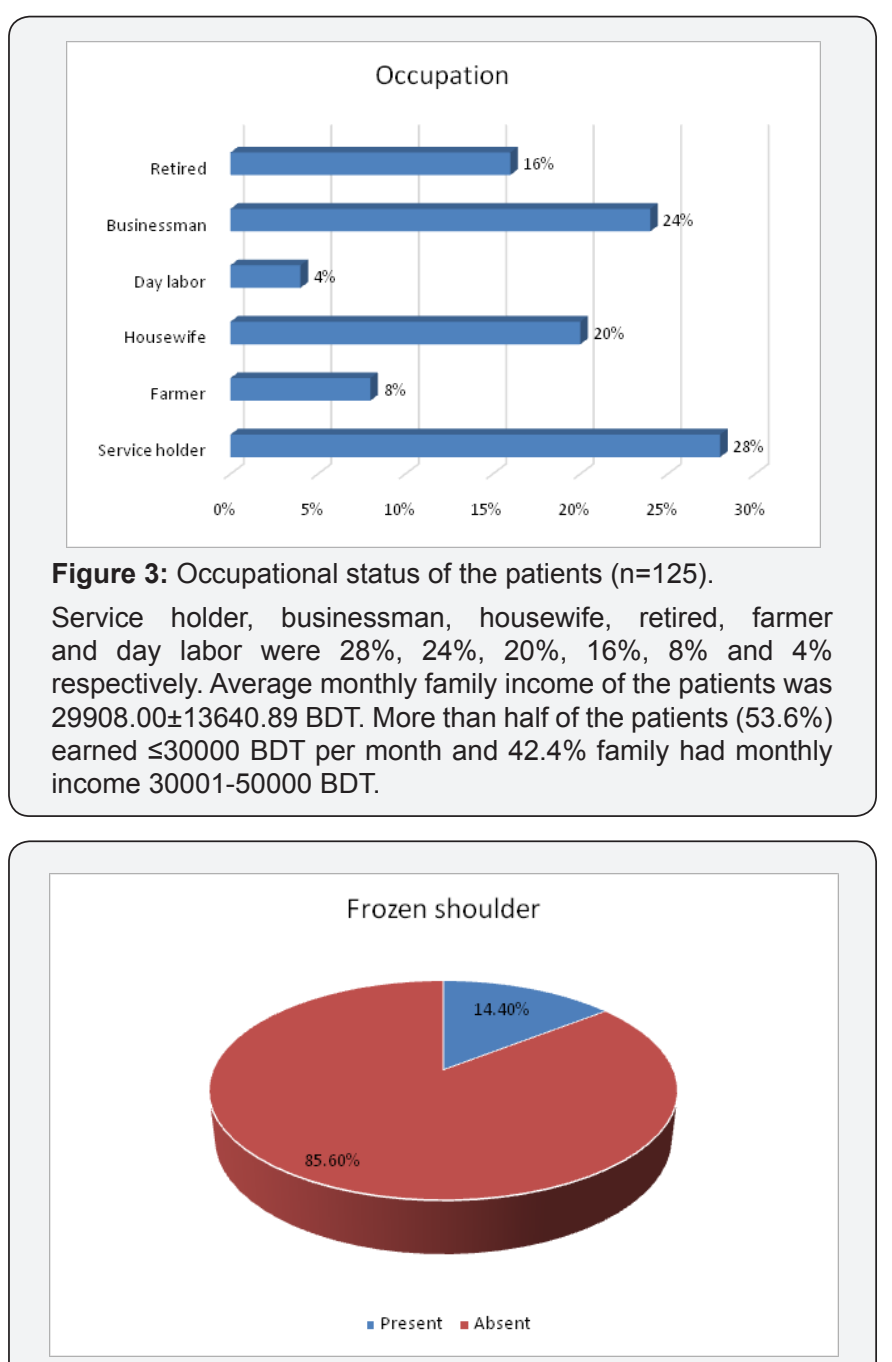

Figure 4: Prevalence of frozen shoulder among diabetic patients $(n=125)$.

Prevalence of frozen shoulder among diabetic patients was $14.40 \%$. No statistical association was found between frozen shoulder and gender $(p=0.488>0.05)$.
Table 1: Age group distribution of the patients $(n=125)$.

\begin{tabular}{|c|c|c|}
\hline Age group in years & Frequency & Percentage \\
\hline Mean \pm SD & $53.16 \pm 11.39$ & \\
\hline $35-50$ & 60 & 48 \\
\hline $51-65$ & 45 & 36 \\
\hline$>65$ & 20 & 16 \\
\hline Total & 125 & 100 \\
\hline
\end{tabular}

Table 2: Monthly family income of the patients $(n=125)$.

\begin{tabular}{|c|c|c|}
\hline Monthly Income & Frequency & Percentage \\
\hline Mean \pm SD & $29908.00 \pm 13640.89$ & \\
\hline$\leq 30000$ & 67 & 53.6 \\
\hline $30001-50000$ & 53 & 42.4 \\
\hline$>50000$ & 5 & 4 \\
\hline Total & 125 & 100 \\
\hline
\end{tabular}

Table 3: Association between frozen shoulder and gender $(n=125)$.

\begin{tabular}{|c|c|c|c|c|c|}
\hline \multirow{2}{*}{ Gender } & \multicolumn{2}{|c|}{ Frozen Shoulder } & Total & $\chi \mathbf{2}$ & $\mathbf{p}$-value \\
\hline & Present & Absent & & & \\
\hline Female & $10(8)$ & $50(40)$ & $60(48)$ & & \\
\hline Male & $8(6.4)$ & $57(45.6)$ & $65(52)$ & 0.481 & 0.488 \\
\hline Total & $18(14.4)$ & $107(85.6)$ & $125(100.0)$ & & \\
\hline
\end{tabular}

\section{Discussion}

Diabetes has multiple complications on nerve, vessel and ultimately musculoskeletal system but how diabetes affect joint structures still it is unclear and researchable. The present study found $14.4 \%$ diabetic patients had frozen shoulder. Another study found that prevalence of frozen shoulder in diabetic patients was $17.2 \%$ [9] which is quite similar to this present study. Results was similar to study done by Gary S. et al who showed that the prevalence was $12 \%$ [10] and Nilüfer et al. [11] who showed that the prevalence was $24 \%$ and Richard et al. [1] who found that the prevalence was $19 \%$.

Another study confirmed that the point prevalence of frozen shoulder in patients with long-lasting type 1 diabetes was 59\% and the lifetime prevalence was $76 \%$ [12]. So it is clear from the above findings that prevalence of frozen shoulder among diabetic patients is high in different parts of the world which is really a burning issue to discuss and intense study. The present study showed that male and female affected equally but Hussain et al. [9] found female are affected more than male but why it is happening need to be study in depth. As a cross sectional study design it was difficult to gather details information about associated diseases or complications but in future I will try to conduct case control or follow up study. If large scale can be done the result will be more precise.

\section{Conclusion}

It is concluded that prevalence of frozen shoulder among diabetic patients is high that means one among seven diabetic patients are suffering from frozen shoulder. 


\section{References}

1. Dias R, Cutts S, Massoud S (2005) Clinical Review of Frozen shoulder. BMJ 331(7530): 1453.

2. lvio E Inzucchi (2008) Diabetes mellitus. Lee Goldman/ Saunders Elsevier. Cecil Medicine, (23 ${ }^{\text {rd }}$ edn), pp. 1123-1178.

3. Alvin C Powers (2008) Diabetes mellitus. Fauci/McGraw-Hill's Harrison's principle of internal medicine, (17 ${ }^{\text {th }}$ edn), pp. 1289-1316.

4. Rizk TE, Pinals RS (1982) Frozen shoulder. Semin Arthritis Rheum 11 440-452.

5. Reeves B (1976) The natural history of the frozen shoulder syndrome. Scand J Rheumatol 4(4): 193-196.

6. Shaffer B, Tibone JE, Kerlan RK (1992) Frozen shoulder. A long term follows up. J Bone Joint Surg Am 74(5): 738-746.

7. Pal B, Anderson J, Dick WC, Griffiths ID (1986) Limitation of joint mobility and shoulder capsulitis in insulin- and non-insulin-dependent diabetes mellitus. Br J Rheumatol 25(2): 147-151.
8. Bunker TD Anthony PP (1995) The pathology of frozen shoulder. A Dupuytren-like disease. J Bone Joint Surg Br 77: 677-683.

9. Hussain MAA (2010) Prevalence of Frozen Shoulder among Diabetic Patients. Medical Journal of Babylon 7(1-2): 291-301.

10. Gary S Perlmutter, Kenneth Sabbagg, William Apruzzese, Enrico Cagliero, David M Nathan (1995) Adhesive capsulitis of the shoulder: a comprehensive study. Massachusetts general hospital, university of California at Los Angeles medical center. 1995: 100-102.

11. Balci N, Balci MK, Tüzüner S (1999) Shoulder Adhesive Capsulitis and Shoulder Range of Motion in Type II Diabetes Mellitus Association with Diabetic Complications. J Diabetes Complications 13(3): 135-140.

12. Juel NG, Brox JI, Brunborg C, Holte KB, Berg TJ (2017) Very High Prevalence of Frozen Shoulder in Patients with Type 1 Diabetes of More than 45 Years' Duration. The Dialong Shoulder Study. Archives of Physical Medicine and Rehabilitation 98(8): 1551-1559.

\section{Your next submission with Juniper Publishers will reach you the below assets}

- Quality Editorial service

- Swift Peer Review

- Reprints availability

- E-prints Service

- Manuscript Podcast for convenient understanding

- Global attainment for your research

- Manuscript accessibility in different formats

( Pdf, E-pub, Full Text, Audio)

- Unceasing customer service

Track the below URL for one-step submission https://juniperpublishers.com/online-submission.php 